See discussions, stats, and author profiles for this publication at: https://www.researchgate.net/publication/292612166

\title{
The Development of Case in Germanic
}

Chapter · November 2009

DOI: $10.1075 /$ slcs.108.09bar

1 author:

Jóhanna Barðdal

Ghent University

62 PUBLICATIONS 715 CITATIONS

SEE PROFILE

Some of the authors of this publication are also working on these related projects:

ERC-funded Project: EVALISA (The Evolution of Case, Alignment and Argument Structure in Indo-European) View project 


\title{
The Development of Case in Germanic*
}

\author{
Jóhanna Barðdal \\ University of Bergen
}

In this article five existing explanations for the loss of case morphology in the Germanic languages are examined. These are (1) phonological erosion, (2) a change from synthetic to analytic, (3) a change from free to fixed word order, (4) the development of the definite article, and (5) a change from lexical to structural case. All five explanations are rejected in favor of (6) a usage-based constructional approach where the breakdown of the case system is expected on the basis of the fact that the argument structure constructions are partially synonymous. Hence, it is predicted that the case and argument structure constructions will either merge, with subsequent loss of case distinctions and case morphology, or that high type frequency constructions will attract new verbs and verbs from low type frequency constructions, gradually causing them to fall into disuse. English, Mainland Scandinavian and Dutch have taken the former path, while German, Icelandic and Faroese have developed along the latter.

\section{Introduction}

The loss of morphological case in the Germanic languages has been subject to substantial research for a long time in linguistics, without any general consensus on its causes. In this article I review five hypotheses on the loss of case morphology and show that none of them holds for Germanic. I then put forward the sixth hypothesis and show that it is compatible with the wide range of relevant data. I begin with a discussion of the classical hypothesis that phonological erosion caused the deflection (section 2). I argue that the predictions of that hypothesis are not borne out, as phonological erosion should apply to verbal suffixes as well as nominal endings, which, however, is not the case in the history of Swedish.

Then, in section 3, I examine the traditional axiomatic assumption that the Germanic languages have developed from being synthetic to analytic, and that this has ultimately caused the case system to breakdown. There are several problems with this explanation, like for instance the fact that there are restrictions on the ditransitive construction in Icelandic which has morphological case, not found in English which does not have case marking. Also, the ditransitive construction blossomed in the history of English after case morphology was lost, attracting several verbs that had not occurred in the construction previously. Moreover, dative objects in Icelandic have not unanimously been replaced with prepositional objects, nor are they an unproductive category, as is expected if Germanic is undergoing a change where periphrastic structures are taking over morphological structures.

In section 4 I turn to the idea that there is a relation between free word order and the existence of a morphologically complex case system in a language. I point out that the word order has become more fixed in Icelandic, although the case system is intact.

\footnotetext{
* This article grew out of the last chapter in my dissertation (2001a). I am indebted to the following people for comments and/or discussions: Bill Croft, Östen Dahl, Lars-Olof Delsing, Thórhallur Eythórsson, Cecilia Falk, Mirjam Fried, Joan Maling, Christer Platzack, Graham Trousdale, my coeditor, Shobhana Chelliah, and the audiences in Manchester (2001), GLAC-8 Bloomington, IA (2002), ICCG-2 Helsinki (2002), 17 ICL Prague (2003), Bergen (2005), 17th ICHL Madison, WI (2005) and Naples (2006), where I have presented earlier versions of this work.
} 
The reverse is, however, true for Dutch, where free word order has been maintained while the case system has been lost. Explaining the loss of morphological case with the fixation of the word order does thus not hold across Germanic.

In section $5 \mathrm{I}$ examine the hypothesis that there is a relation between the loss of morphological case and the emergence of the definite article in Scandinavian. I point out that Icelandic and Faroese differ from Mainland Scandinavian in that these languages have developed a definite article, yet they have maintained morphological case. Hence, the emergence of the definite article does not explain the loss of morphological case.

Then, in section 6, I investigate whether the changes in case marking in the Germanic languages are best described as a change from lexical case to structural case, as has been extensively argued for in the literature. I show that there are changes in case marking in Icelandic which directly contradict this hypothesis. First, structurally case marked subjects have changed into lexically case marked subjects. Second, lexically case marked subjects have changed from one lexical case to the other. Third, structural accusative objects have changed into lexical dative objects. Forth, lexical genitive objects have changed into structural nominative objects. Finally, in the history of English, Swedish and Faroese, structural nominative objects have changed into structural accusative objects. Several auxiliary mechanisms have been postulated to account for these changes, all of which are derivatives of case marking facts in Germanic, not predictive per se.

Finally, in section 7, I suggest a usage-based constructional account of the development and argue that its predictions hold for all the Germanic languages, including the development of the 'blended' construction in the history of English, Swedish and Faroese, and case changes in Icelandic in general. As the case and argument structure constructions in Germanic were partly synonymous, there were two logical ways for the case and alignment system to develop: (i) by merging the argument structure constructions, with subsequent loss of case distinctions and case morphology, and (ii) by eliminating the synonymous low type frequency constructions. A usage-based constructional approach, combined with a view of productivity based on type frequency, coherence, and an inverse correlation between the two, predicts that high type frequency constructions will gain in type frequency over time, as they attract new and existing verbs, at the cost of low type frequency constructions. Rapid changes in the vocabulary are expected to speed up the development, as the proportion of new verbs in a language will be higher during periods of language contact than during other periods. As predicted, the development of case correlates with the amount of language contact found in the Germanic language areas, as English has been exposed to the most language contact and earliest, with the loss of case morphology also taking place earlier than in the other languages. Swedish was also exposed to severe contact during the 13th century and later, which coincides in time with the loss of case. German has been exposed to less foreign influence, and has eliminated several of the Germanic low type frequency constructions. Icelandic has been exposed to least foreign influence and maintained most of the Germanic case and argument structure constructions, although the constructions lowest in type frequency have reduced their type frequency even further.

The accounts in sections $2-5$ place the changes in different domains of grammar, i.e. in phonology (2), change in morphological type (3), word order (4), and semantics/definiteness (5). I argue against these approaches presenting empirical data which are incompatible with the predictions derived from them. In contrast, in section 
6 the issue is a theoretical account of a synchronic mechanism of case assignment which has also been applied to historical material. Again, I argue against this account by presenting empirical data that contradict the predictions derived from this approach, as well as showing that the different auxiliary mechanisms developed to account for the whole array of relevant data are derivatives of the empirical facts and not predictive per se. The account in section 7 is also anchored in a particular theoretical approach, which strength lies therein that it accords more straightforwardly with the relevant empirical data than that of the account in 6 . Section 8 contains a summary of the content and conclusions of this article.

\section{Phonological Erosion}

The most classical explanation for the loss of case morphology found in the literature is based on the assumption that the case endings have been wiped out by phonological erosion. Blake (2001: 176-178), for instance, argues that the reduction of unstressed vowels to schwa and the loss of final $-n$ accounts for the breakdown of the case system in the history of English.

Unstressed vowels have of course been reduced to schwa in more languages than English, like in the Scandinavian languages, but the results of this reduction are different for different inflectional categories. The masculine and neuter dative singular ending $-e$ gradually disappeared during the late Old Swedish period (Wessén 1992: 142), while the present tense first person plural ending $-e$, which existed in the same period, was in fact maintained as a marker of number agreement until last century (Wessén 1992: 252-256). It seems that if the reduction, and subsequently the loss, of unstressed vowels is a causal factor, the agreement marker - $e$ should also have been eroded during the late Old Swedish period, which however does not take place until centuries later. This difference in survival between the different $e$-endings, case endings and agreement markers, cannot be attributed to differences in sentence intonation either, as the verb is not placed in a notably more stressed position in the sentence than its arguments are. This example from Swedish shows that phonological erosion cannot be considered a primary cause, as the reduction/loss of unstressed vowels does not apply equally across all inflectional endings but selects out case endings and leaves verbal endings intact.

\section{Synthetic to Analytic}

A change from a synthetic stage of a language to an analytic stage entails that morphological or synthetic structures are replaced with periphrastic structures. For case and argument structure constructions such a change implies that dative objects, i.e. both indirect objects of ditransitives and direct objects of transitives, should be replaced with a prepositional phrase. Several scholars have argued that such a change has taken place in the Mainland Scandinavian languages and that this explains the loss of case marking in that area (cf. Jahr 1995, Faarlund 2001, Askedal 2001). This analysis makes certain predictions about correlating changes in case and argument structure from Old Germanic to the Modern Germanic languages, namely:

- Morphological case should be lost

- Ditransitive constructions should have decreased in frequency

- Dative objects should have been replaced with prepositional objects

These predictions are not uniformly borne out for the Germanic languages. Morphological case has not been lost in Icelandic, Faroese and German, although it 
has gone lost in the other Germanic languages. The ditransitive construction, which is a synthetic construction, should have given way for its analytical counterpart, i.e. the construction where the indirect object is expressed as a PP, and hence the ditransitive should have gone down in frequency if loss of morphological case is a consequence of a development from synthetic to analytic in Germanic. The frequency of the ditransitive construction has, indeed, decreased in frequency in Icelandic, both in type and token frequency:

Table 1. Type and token frequency of the ditransitive construction

\begin{tabular}{lccc}
\hline & Old Norse-Icelandic & Modern Icelandic & Total \\
\hline Types & 41 & 21 & 62 \\
Tokens & 109 & 57 & 166 \\
\hline
\end{tabular}

The figures in Table 1 are extracted from a text corpus, consisting of four Old NorseIcelandic genres and the corresponding genres in Modern Icelandic (see Barðdal 2001a for a detailed description of the corpus), and the differences in type frequency between the two language stages are highly significant (Pearson Chi-square, $p<$ $.000)$. There are examples of ditransitive verbs in the Old Norse-Icelandic material (2a), which in Modern Icelandic can only occur with a prepositional phrase (2b):

(2)a.

... ef pú skyldir skera Vésteini bróður mínum skyrtuna.

if you should cut Vesteinn.DAT brother my shirt-the.ACC

'... if you were to make my brother Vésteinn the shirt.'

b. Ef pú cettir að skera skyrtu handa Vésteini bróður mínum.

(Gísla saga Súrssonar 1987: 859-860)

if you were to cut shirt.ACC for Vésteinn.DAT brother my

'If you were to make a shirt for my brother Vésteinn.'

Moreover, one would not expect novel verbs to occur in the ditransitive construction in Icelandic if the language is or has been changing from synthetic to analytic. This is nevertheless the case, as the following two documented examples with e-maila 'email' and sms- $a$ 'text' show (cf. Barðdal 2003, 2008: Ch. 5):

(3)a. $\quad$... ég reyndi að e-maila pér munstrið en boxið pitt er fullt.

I tried to email you.DAT pattern-the.ACC but box-the yours is full

'... I tried to email you the pattern but your inbox is full.'

b. (www.handavinna.is/spjall/read.php? $\mathrm{f}=14 \& \mathrm{t}=77 \& \mathrm{a}=1$ )

... og bað hana um að sms-a mér svefntöflu.

and asked her about to text me.DAT sleeping-pill.ACC

'... and asked her to text me a sleeping pill.'

(drherdis.blogspot.com/2004_01_01_drherdis_archive.html)

In fact, one would expect Icelandic to have the least restrictive ditransitive construction, while the languages that have lost morphological case should have a more restricted ditransitive. This prediction is not borne out. What is more, facts seem to be exactly the opposite:

(4)a. I'll throw you the ball.

English

b. *Ég hendi pér boltann/boltanum.

Icelandic

I throw you.DAT ball-THE.ACC/ball-THE.DAT 
The examples in (4) show that verbs of throwing, for instance, can occur in the ditransitive construction in English while they cannot occur in it in Icelandic (cf. Barðdal 2007). Verbs of obtaining and verbs of making, for instance, are not as acceptable in the ditransitive construction in Icelandic, as they are in English:

(5)a. * *Get ég keypt pér glas af víni?

Icelandic can I buy you.DAT glass of wine

b. Can I buy you a glass of wine?

English

(6)a. $\quad * E ́ g$ skal hrista/blanda pér smá sallad.

Icelandic

I will toss/mix you little salad

b. I'll toss you some salad.

English

It is also a fact that it was not until after the breakdown of the case system in English that the ditransitive construction became productive, being extended to all kinds of verbs that had not occurred in it earlier (cf. Visser 1963: 629). Hence, morphological case and analytic/synthetic structures are not necessarily in complementary distribution in the Germanic languages, which again undermines the validity of an explanation based on the synthetic-analytic dichotomy.

With regard to the last prediction in (1) above, that dative direct objects should have been replaced with prepositional objects, there are examples that seem to confirm this. Consider the following:

(7)a. Dórgunna vildi engum mat bergja um kveldið. Old Norse-Icelandic Thórgunna wanted no food.DAT taste around evening

'Thórgunna didn't want to eat anything in the evening.'

b. $\quad$ Ég hafði bergt á hreinu og toeru vatninu ...

(Eyrbyggja saga 1987: 603)

I had tasted on clean.dat and clear.dat water-the.dat

'I had tasted the crystal clear water ...'

(www.sigurfreyr.com/krishnamurti.html)

In Old Norse-Icelandic the verb bergja 'taste' could either occur with a direct object or with a prepositional object, whereas in Modern Icelandic only the prepositional variant exists. This seems to suggest that dative objects have been replaced with prepositional objects. However, the reverse is also found in the history of Icelandic, since verbs which could occur with a prepositional object in Old Norse-Icelandic only select a dative direct object in Modern Icelandic. One such verb is heilsa 'greet':

(8)a. Hann heilsaði á konung.

Old Norse-Icelandic

he greeted on king. ACC

'He greeted the king.' (Óttars páttur svarta 1987: 2205-2206)

b. Hann heilsaði konungi/*á konung

Modern Icelandic

he greeted king.DAT/on king.ACC

'He greeted the king.'

It is thus not at all evident that dative direct objects have been replaced with prepositional objects. In fact, it seems that some verbs selecting for dative direct objects can now only select for prepositional objects, and vice versa that verbs selecting for prepositional objects earlier can now only select for dative objects. 
A development from synthetic to analytic would also entail that new verbs in Icelandic should not select for dative objects. This is, however, far from being true. In a recent study (Barðdal 2006a), I have shown that borrowed verbs assign dative case to their objects in approximately $37 \%$ of the cases (cf. also Barðdal 2001a: 124). The exact numbers are given in Table 2 . The productivity of the dative object construction has also been documented in 15th century Icelandic (cf. Barðdal 1999). This evidence further illustrates that a change from synthetic to analytic does not provide a fruitful explanatory model for the development of case in Germanic.

Table 2. The assignment of Nom-Acc and Nom-Dat to borrowed verbs in Icelandic

\begin{tabular}{lrr}
\hline & $\mathrm{N}$ & $\mathrm{f}$ \\
\hline Nom-Acc & 67 & $63.2 \%$ \\
Nom-Dat & 39 & $36.8 \%$ \\
Total & 106 & $100.0 \%$ \\
\hline
\end{tabular}

To summarize, in this section I have discussed and rejected the predictions of the hypothesis that there has been a development from synthetic to analytic in the Germanic languages. First, there are restrictions found on the ditransitive construction in Icelandic which are not found with the ditransitive construction in English, in spite of the fact that Icelandic has maintained morphological case whereas English has not. Second, the ditransitive construction became extremely productive in the history of English after the case system broke down. Third, there is no evidence that dative direct objects have consistently been replaced with prepositional objects in the history of Icelandic. Fourth and finally, one would not expect new verbs to assign dative case to their objects, which is exactly what approximately $37 \%$ of borrowed verbs in Icelandic do. The predictions of the synthetic-to-analytic hypothesis are thus not borne out in Germanic.

\section{Case and Word Order}

It is a widely assumed hypothesis, ever since at least Falk and Torp (1900: 203??), that there is an inherent causal relation between word order and case morphology (Sapir 1921, Venneman 1974, Kemenade 1987, Lehmann 1985, Neeleman and Weerman 1999). That is, the more morphological cases the freer the word order, and the fewer (or no) morphological cases the more fixed the word order is in a language. Many scholars have suggested that the loss of case marking in Mainland Scandinavian is related to the word order becoming more fixed in these languages (Anward and Swedenmark 1997, Askedal 2001, Faarlund 2001). On this analysis one can expect the following correlating changes:

$$
\begin{aligned}
& \text { - The word order becomes more fixed } \\
& \text { - Morphological case is lost }
\end{aligned}
$$

There are, however, two languages within the Germanic language family that pose serious problems for such an account and these are Icelandic and Dutch. Icelandic has certainly undergone a change from Old Norse-Icelandic to Modern Icelandic, similar to the other Scandinavian languages, in that the word order has become more fixed, despite the fact that Icelandic has not lost its case system. This change is most clearly manifested in lack of OV word order in Modern Icelandic and a lesser prominence of discontinuous phrases (Rögnvaldsson 1995, Barðdal and Eythórsson 2003a). Dutch, however, has a much freer word order than Icelandic, as it has for instance retained 
$\mathrm{OV}$, discontinuous phrases and various scrambling possibilities that are non-existent in Modern Icelandic. Dutch has nevertheless lost its case system. My conclusion is, therefore, that while there may well be a typological tendency for case languages to have freer word order than non-case languages, there is, however, no direct causal relation here. Hence, the development of more fixed word order in Scandinavian is not a feasible explanation for the breakdown of the morphological case system.

\section{Case and the Definite Article}

It has also been proposed that the loss of morphological case in Scandinavian is related to the emergence of the definite article (Holmberg 1994, Anward and Swedenmark 1997). This hypothesis is partly based on the typological fact that many case languages do not exhibit a definite article, like the Finno-Ugric languages, and partly on the fact that the emergence of the definite article in Scandinavian seems to have taken place at the same time as case marking disappears. Hence, on this analysis, the following correlating changes are expected:

$$
\begin{aligned}
& \text { - A definite article emerges } \\
& \text { - Morphological case is lost }
\end{aligned}
$$

There are, however, two languages within the North Germanic language family that pose a serious problem for this analysis, namely Icelandic and Faroese. Both these languages have acquired a definite article, presumably at roughly the same time as the definite article was acquired in Mainland Scandinavian. Therefore, the emergence of the definite article seems to be a common Scandinavian innovation. However, neither Icelandic nor Faroese have lost their case system. Thus, it cannot be assumed that there is a direct causal relation between the emergence of the definite article and the breakdown of the case system in Mainland Scandinavian, despite the fact that these changes seem to occur at approximately the same time.

\section{Structural vs. Lexical Case}

Many scholars have argued that the breakdown of the case system in Germanic is a manifestation of structural case replacing lexical case (see Delsing 1991 and Falk 1997 for Swedish, Allen 1995 and Lightfoot 1999 for English, Askedal 2001 for Scandinavian, Eythórsson 2000, 2002 for Icelandic, and Barnes 1986 and Jónsson and Eythórsson 2005 for Faroese). Structural case is nominative on subjects and accusative on objects, assigned on the basis of the structure of the sentence (henceforth given with capitals, for ease of disposition, in this section). All other case marking of direct arguments is regarded as lexical, i.e. assigned more or less idiosyncratically by individual lexical verbs, and hence it is word-bound (henceforth given with lower-level letters). The predictions of the lexical-to-structural-case analysis should manifest itself in the following changes (either one or the other):

$$
\begin{aligned}
& \text { - Loss of morphological case } \\
& \text { - Structural case forms replace lexical case forms: } \\
& \text { Acc/Dat/Gen subjects }>\text { NoM subjects }{ }^{1}
\end{aligned}
$$

\footnotetext{
${ }^{1}$ It has been generally assumed in the linguistic literature, ever since Andrews (1976), that Modern Icelandic (and Modern Faroese) has syntactic subjects in all its four morphological cases, i.e. nominative, accusative, dative and genitive (see Table 3 below). This entails a definition of subjecthood which is not based on morphological criteria, like nominative case and agreement, but on syntactic criteria, i.e. first position in declarative clauses, inverted position in questions, first position in
} 


\section{Dat/Gen objects $>$ ACC objects}

The replacement of lexical case with structural case can involve a complete breakdown of the morphological case system, with case distinctions, at best, only present in pronouns. This has happened in English, Dutch and Mainland Scandinavian. It can also entail nominative becoming the subject case, accusative becoming the object case, dative becoming the case for indirect objects and genitive the case for nominal attributes, which is approximately what has happened in standard German.

The predictions in (11) above are, however, not borne out for Icelandic. There are plenty of examples in the history of Icelandic of accusative subjects changing into not NOMINATIVE subjects but dative subjects, i.e. the so-called dative substitution (see Svavarsdóttir 1982, Halldórsson 1982, Rögnvaldsson 1983, Svavarsdóttir et al. 1984, Smith 1994, Eythórsson 2000, 2002, Barðdal 2001a: 134-138, 2004, Jónsson and Eythórsson 2005):

$$
\begin{aligned}
& \text { Mig langar }>\text { Mér langar } \\
& \text { me.ACC longs }>\text { me.DAT longs }
\end{aligned}
$$

There are also examples of NOMINATIVE subjects changing into dative subjects:

$$
\begin{aligned}
& \text { Ég hlakka til > Mér hlakkar til } \\
& \text { I.NOM look.1P forward }>\text { me.DAT looks.3P forward }
\end{aligned}
$$

subordinate clauses, subject-to-subject raising, subject-to-object raising, conjunction reduction, control infinitives, clause-bound reflexivization, and long distance reflexivization. With regard to these syntactic properties, it is systematically the leftmost argument of the argument structure in Icelandic which shows this behavior, irrespective of whether this argument is in the nominative or some other morphological case. This has been heavily discussed in the international literature on Icelandic and the Germanic languages in general, of which the latest contribution can be found in Barðdal (2006b) where Modern Icelandic and Modern German are compared. This syntactic, as opposed to morphological, approach to grammatical relations also entails that rightmost arguments of the argument structure in Icelandic, which are case-marked in the nominative, are analyzed as objects. Syntactic properties of objects in Icelandic are their position to the right of the main verb in declarative clauses and their ability to undergo object shift. The nominative arguments in Icelandic which behave in this way are the nominatives of Dat-Nom predicates (see again Table 3 below). In all the respects listed above, syntactic subjects and syntactic objects differ in their distributional and syntactic behavior, and given these syntactic criteria it is clear that morphological case marking and grammatical relations do not coincide in Icelandic. It has also been shown that at least for the Germanic language family, which is in focus in this article, that there are structures containing subject-like obliques in Old Norse-Icelandic, Old Swedish, Early Middle English and Modern German that call for a subject analysis, i.e. structures where an object analysis does not give a satisfactory account of the data (Eythórsson and Barðdal 2005). Hence, it seems as oblique or non-nominative subjects are a Germanic inheritance.

I want to emphasize, however, that the analysis of the development of case in Germanic, presented in this article, does not hinge upon the reader agreeing on the subject analysis of oblique subjects or the object analysis of nominative objects. The analysis on the development of case, presented here, is an analysis of argument structure constructions and the alignment of morphological case across these, and how changes in this alignment have taken place. There is no disagreement in the literature that Dat-Nom argument structure constructions are Dat-Nom argument structure constructions, and that the dative argument is the leftmost argument while the nominative argument is the rightmost argument of the argument structure, irrespective of grammatical relations. A reader who has conceptual problems with the idea that syntactic subjects can be in another case than the nominative and that syntactic objects can be in the nominative case should just read oblique subject as meaning 'non-nominative subject-like argument' and nominative object as 'nominative object-like argument' in the remainder of this article. 
Dative substitution is also well known from the history of English, German and Swedish (see sections 7.1-7.3 below and the references there).

The example in (12) illustrates that a lexical accusative is being replaced with a lexical dative with the verb langa 'long for'. The one in (13) exemplifies structural NOMINATIVE being replaced with lexical dative with the verb hlakka til 'look forward'. Therefore, with regard to subject case marking, the predictions of the lexical-to-structural-case hypothesis are far from being borne out in Icelandic, as lexical case is not being replaced with structural case but another lexical case (12), and structural case is in fact being replaced with lexical case (13).

It is a well-known fact, however, that dative substitution only targets experiencerbased predicates, which in turn has given rise to yet another dichotomy within the generative tradition, namely the thematicity-idiosyncraticity dichotomy (Zaenen, Maling and Thráinsson 1985, Jónsson 2003, Jónsson and Eythórsson 2005). Changes in case marking, as in (12-13), are assumed to take place on the basis of the semantics of these predicates, hence the term 'thematic'. Other non-structural case marking, and changes in case marking, not based on semantic factors, are considered 'idiosyncratic.' Hence, in order to rescue the case assigning mechanism based on the structural-lexical dichotomy, additional auxiliary devices, like a dichotomy between thematic and idiosyncratic case, must be invented.

Turning to objects, there are verbs that could occur with either ACCUSATIVE or dative objects in Old Norse-Icelandic, which can only occur with dative objects in Modern Icelandic (14), and conversely, verbs that could occur with either ACCUSATIVE or dative objects in Old Norse-Icelandic can only occur with ACCUSATIVE objects in Modern Icelandic (15):

(14)a. ... en fyrir pví að ... glataði hann höfuð sitt ...

Old Norse-Icelandic but for it that ... lost he head.ACC his.ACC

'... but because of that ... he lost his head ...'(Physiologus 1991: 46-48)

b. Hann hafði glatað höfði sinu/*höfuð sitt.

Modern Icelandic he had lost head.DAT his.DAT/head.ACC his.ACC

(15)a. ... að enginn riddari stenst honum.

Old Norse-Icelandic that no knight withstands him.DAT '... that no knight is his equal.' (Ívens saga 1979: 95-99)

b. Enginn riddari stenst hann/*honum. Modern Icelandic no knight withstands him.ACC/him.DAT

In (15) a lexical dative is being replaced with a structural ACCUSATIVE with the verb standast 'withstand', whereas (14) is an example of structural ACCUSATIVE being replaced with lexical dative with the verb glata 'lose', which is unexpected on the lexical-to-structural-case account. In addition, dative objects should not be a productive category in Icelandic, as dative objects are lexically case marked (cf. Barðdal 2001a: 119-121), but as already discussed in section 3 above, 37\% of transitive verbs borrowed into Icelandic assign dative case to their objects.

In an article from 1993 I pointed out that it is very common that verbs of motion assign dative case to their objects in Icelandic. This has gradually led to a redefinition of dative objects within the generative paradigm, and now dative case on objects in Icelandic is divided into thematic and idiosyncratic case assignment, i.e. thematic case assignment with motion verbs and idiosyncratic case assignment with other dative 
object verbs (Jónsson 2003: ??-??). This of course raises the more general question of whether the whole dichotomy between thematic and idiosyncratic case may simply be a consequence of lack of research on case assignment of low-level verb-subclassspecific constructions.

On the lexical-to-structural-case account, moreover, it is expected that genitive objects be replaced with ACCUSATIVE objects because genitive on objects is regarded as lexical whereas accusative on objects is regarded as structural. Such cases exist; examples like those in (16) with the verb purfa 'need' are well known from the history of Icelandic.

(16)a. ... og parf Hersteinn nú pinna heillaráða. Old-Norse Icelandic ... and needs Hersteinn now your.GEN good-advice.GEN

'... and Hersteinn is now in need of your good advice.' I need all.ACC attention.ACC at father mine too 'I need all my father's attention too.'

(barnaland.mbl.is/barn/19508/vefbok/8)

However, it is not expected on the lexical-to-structural-case account that genitive objects change into NOMINATIVE objects. Such a change is also found from Old Norse-Icelandic to Modern Icelandic. Consider the verb batna 'recover from' which selected for a genitive object in Old Norse-Icelandic (17a) but selects for a NOMINATIVE object in Modern Icelandic (17b):

(17)a. Dormóði batnaði pá skjótt augnaverkjarins og ... Old Norse-Icelandic Thormod.DAT got-better then swiftly eye-pain-the.GEN

'Thormod then swiftly recovered from the eye pain ...'

b. $\quad$... og Steinunni batnaði veikin.

(Fóstbræðra saga 1987: 802)

... and Steinunn.DAT got-better illness-the.NOM

'... and Steinunn recovered from the illness.'

(www.snerpa.is/net/thjod/fellsend.htm)

On a lexical-to-structural-case account it is expected that a lexical genitive changes into a structural ACCUSATIVE (cf. Falk 1997: 77-78), but that is not the case in the history of Icelandic with all genitive object verbs, as (17) shows. Hence, the predictions of the lexical-to-structural-case account are clearly not borne out in Icelandic.

It must be pointed out that the existence of NOMINATIVE objects has been dealt with within generative grammar (cf. Yip, Maling and Jackendoff 1987, Sigurðsson 1989 and subsequent work, Jónsson 1996), which is needed as the case assigning mechanism originally postulated within this framework predicts that NOMINATIVE objects should not exist, since nominative is supposed to be the structural case for subjects and accusative to be the structural case for objects. Yip, Maling and Jackendoff's modified account is based on the idea that structural case is assigned to the first argument in the clause which is not lexically case marked, in this case the object, as the subject is already case marked with a lexical dative. Thus, in order to account for the existence of NOMINATIVE objects, the original concept of structural case being divided into NOMINATIVE on subjects and ACCUSATIVE on objects has 
been abandoned. Yip, Maling and Jackendoff (1987: 224) make a note of this themselves. The problem, however, with their modified account is that it then predicts that predicates with lexically case-marked subjects should assign structural NOMINATIVE to their objects instead of the structural ACCUSATIVE case which is documented with these predicates in Middle English, Old Swedish and Modern Faroese:

for pi ðat him areowe ow

Middle English

for that that him.OBL pity you.OBL

'so that he would pity you' (Allen 1995: 238)

Honom thykte sik wara j enom lystelikom stadh

Old Swedish he.OBL thought himself.OBL be in a pleasing place

'He felt as if he was in a pleasant place.' (Falk 1997: 77)

Mcer dámar voel hasa bókina.

Modern Faroese

I.DAT like well this book.ACC

'I like this book.' (Barnes 1986: 33)

The verbs in (18-20) above are all originally Dat-Nom verbs and yet there has been a change from NOMINATIVE objects to ACCUSATIVE objects, i.e. from one structural case to another. ${ }^{2}$ On Yip, Maling and Jackendoff's account, this should not happen, as structural NOMINATIVE should be assigned here and not structural ACCUSATIVE, because of the lexical case marking of the subject. Hence, the original case assigning mechanism, that objects receive ACCUSATIVE case, must be invoked to account for this change. In other words, the original case assigning mechanism which was used to account for the changes in object case marking of purfa in (16) makes wrong predictions about the object case marking of batna in (17), hence it needs to be modified. However, this modified case assigning mechanism makes wrong predictions about the 'blended' construction in the history of Germanic (18-20), hence the original case assigning mechanism must be invoked again. Clearly, therefore, these two case assigning mechanisms are simply derivatives of case marking facts in Germanic instead of being predictive. I return to the case marking of the 'blended' construction in section 7.5 below where I argue that the change in case marking is motivated by differences in type frequency between NOMINATIVE and ACCUSATIVE objects.

To summarize the content of this section, I have shown that the predictions of the lexical-to-structural-case account are not borne out for Icelandic. Both structural and lexical case on subjects have been replaced by lexical case (dative substitution). This has given rise to a dichotomy of case assigning mechanism based on the notion of thematic vs. idiosyncratic case. There are also changes from ACCUSATIVE to dative on objects in the history of Icelandic, unexplained and unexpected, as structural object case must then have been replaced with lexical object case. Finally, genitive objects have changed into NOMINATIVE objects, which is also unexpected on the lexical-to-

\footnotetext{
${ }^{2}$ All existing Old Swedish examples of thykia 'feel, seem' together with a small clause are ambiguous between a nominative and accusative form of the pronoun of the lower argument, thus it is not given that thykia was a Dat-Nom verb when selecting for small clauses in Old Swedish. However, since the cognate of thykia in the earliest period of the other Germanic languages was a Dat-Nom verb it is reasonable to believe that this is a common Germanic inheritance, which has already been lost, or is in the process of being lost, at the time of the oldest Swedish examples.
} 
structural-case account, but can be explained by a modified case mechanism which assumes that an object gets structural NOMINATIVE if the subject is already lexically case marked. However, this modified case assignment mechanism does not explain the change from NOMINATIVE objects to ACCUSATIVE objects in the history of English, Swedish and Faroese, although the original case assigning mechanism that ACCUSATIVE case is assigned to objects does. Hence, generative grammar must make use of several different auxiliary mechanisms to account for case marking in Icelandic and changes in case marking in the history of Germanic, in addition to the original mechanism that NOMINATIVE and ACCUSATIVE are assigned on the basis of their structure in the sentence. Clearly, these auxiliary mechanisms are simply derivatives of case marking facts in Germanic instead of being predictive. As such they are of limited explanatory value.

\section{A Usage-Based Constructional Approach}

In construction grammar constructions are the basic units of language, central to all linguistic descriptions and theories of language (Goldberg 1995, 2005, Barðdal 2001a-b, 2004, 2006a-b, Croft 2001, Michaelis and Ruppenhofer 2001, Boas 2003, Croft and Cruse 2004, etc.). Constructions are form-meaning correspondences, found at all linguistic levels, including the sentence level. The meaning of a construction is either general, i.e. derivable from the meaning of the parts, or specific, i.e. not derivable from the meaning of the parts. The ordinary transitive construction is an example of the former, while more idiomatic constructions, like the What's X doing Y? construction (found in examples like What's that fly doing in my soup?) (cf. Kay and Fillmore 1999), are examples of the latter. On the constructional approach advocated here, all linguistic objects count as constructions, as all linguistic objects are form-function correspondences of some sort. This means that not only idiomatic expressions are regarded as constructions of their own, but also ordinary argument structure constructions with different case frames. A usage-based constructional account differs from non-usage-based constructional accounts in that it takes the frequency of constructions to be central to their status in the language system (cf. Barlow and Kemmer 2000). The focus here is first and foremost on type frequency, both absolute type frequency (dictionary frequencies) and relative type frequency (type frequencies based on occurrences in texts) (see, furthermore, Barðdal 2008 on the interrelation between type and token frequency for productivity).

Table 3. Case constructions in earlier Germanic

\begin{tabular}{llll}
\hline Nom & Acc & Dat & Gen \\
\hline Nom & Acc & Dat & Gen \\
Nom-Acc & Acc-Nom & Dat-Nom & Gen-Nom \\
Nom-Dat & Acc-Acc & Dat-Gen & Gen-PP \\
Nom-Gen & Acc-Gen & Dat-PP & Gen-S \\
Nom-PP & Acc-PP & Dat-S & \\
Nom-S & Acc-S & & \\
\hline
\end{tabular}

Morphological case is an indistinguishable part of argument structure constructions in languages with case morphology (Barðdal 2001a: 33-39, Fried 2005), and different case frames are only one of the formal features of argument structure constructions. Table 3 gives an overview of the case constructions of one and two-place predicates (aligned according to the case marking of the subject) documented in the history of Icelandic, and as no other case constructions seem to be inherited from Proto- 
Germanic, Table 3 should accurately represent the case constructions common for the Germanic language area before the breakdown of the case system in the individual languages. By case construction I refer to the argument structure constructions in Germanic which are marked by the case frames in Table 3.

With regard to the semantics of the various argument structure constructions, it is a fact that there is a substantial overlap between the different constructions in Icelandic (Barðdal 2001a: 35-36, 2008). The nominative subject construction (which includes both one- and two-place predicates) is the construction highest in type frequency and semantically the most open construction, as verbs from all semantic classes can have a nominative subject, i.e. both agentive and non-agentive verbs. The oblique-subject constructions, however, differ from the nominative subject construction in that they can only be non-agentive; The genitive subject construction (10-15 types) is mostly instantiated by predicates denoting ontological or perceived states (cf. Barðdal 2001a: Appendix B):

Dess varð vart i gömlum textum.

Genitive subject

it.GEN was susceptible in old texts

'This could be discerned in old texts.'

The accusative (200 types) and dative (700 types) subject constructions, however, are instantiated in part by stative and inchoative experience-based predicates (ex. 22 below) and in part by anti-causative intransitives (ex. 23 below):

(22)a. Mig svíður i handlegginn.

Accusative subject

me.ACC itches in arm

'I itch on the arm.'

b. Mér brá.

Dative subject

me.DAT got-startled

'I was startled.'

(23)a. Bátinn raká land. boat.ACC drifted on shore

Accusative subject

'The boat drifted ashore.'

b. Henni skaut upp á stjörnuhiminninn á einni nóttu. Dative subject her.DAT shot up on star-heaven on one night

'She became a star overnight.'

Anti-causative intransitives are intransitive variants of causative verbs where the object of the causative is the subject of the intransitive) (cf. Barðdal 2001b, 2004).

This means that there is a semantic overlap between the accusative and the dative subject constructions. These two, in turn, overlap with the nominative subject construction, as the nominative subject construction is the semantically most open construction. This can tentatively be represented as in Figure 1, where the Nominative subject construction, at the top of the figure, stretches over the entire semantic field, because it is semantically open and highest in type frequency. As the type frequency of the Accusative, Dative and Genitive subject constructions is much lower, they only cover a fraction of the semantic field that the nominative covers. Moreover, there is substantial semantic overlap between the Accusative and the Dative subject constructions, as these were instantiated by verbs from the same semantic classes in the individual Germanic languages. Hence, they partly occupy the same semantic 
space in Figure 1. The genitive subject construction does not overlap with the Accusative and the Dative subject constructions, hence it is located elsewhere in semantic space. All three oblique subject constructions, however, overlap with the Nominative subject construction, as experience-based predicates, anti-causative intransitives, ontological and perceived states could also be instantiated by the Nominative subject construction. Hence their corresponding spaces in Figure 1 all overlap with the space for the Nominative subject construction. This is the reason that the four different subject constructions were partly synonymous in Earlier Germanic.

Nom

Dat

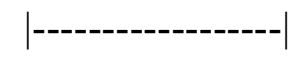

Acc

Gen

Figure 1. The semantic overlap between the nominative, dative, accusative and genitive subject constructions

Observe that Figure 1 does not lay out the relevant semantic dimensions. It is only meant to graphically illustrate the semantic overlap in relation to the type frequencies of each construction. For a more detailed account of the semantic overlap between the individual case constructions, I refer the interested reader to Barðdal (2001a) for an account in terms of thematic roles, and to Barðdal $(2004,2008)$ for an account in terms of semantic verb classes.

It is a well-known fact in linguistics that languages have a tendency to avoid synonymous grammatical forms (see Goldberg 1995: 67, and the references cited there). The loss of morphological case in the individual Germanic languages can be regarded as a consequence of this, since the various case constructions are partly synonymous with each other (cf. also Luraghi 1987). Given that, there are logically two ways for languages to evolve:

- The morphological case distinctions disappear with a subsequent "merging" of the argument structure constructions

- High type frequency constructions attract verbs from low type frequency constructions, thereby gradually causing low type frequency constructions to fall into disuse

As we will see below, Mainland Scandinavian, English and Dutch seem to have evolved in the former way, as the case constructions have disappeared in these languages, whereas German, Icelandic and Faroese have moved along the latter path, with the case constructions highest in type frequency being generalized at the expense of the other constructions lower in type frequency.

According to a usage-based constructional approach to productivity (cf. Bybee 1995), productivity is a function of type frequency and coherence. In this particular case it is a question of syntactic productivity, and I have argued elsewhere that the coherence at issue for the productivity of argument structure constructions is semantic coherence, with the term semantic coherence refering to the internal semantic consistency between the relevant predicates. It follows from this approach that 
productivity is a function of the type frequency of an argument structure construction and its semantic coherence, and an inverse correlation between the two (cf. Barðdal 2006a, 2008). This can be modeled as in Figure 2 below:

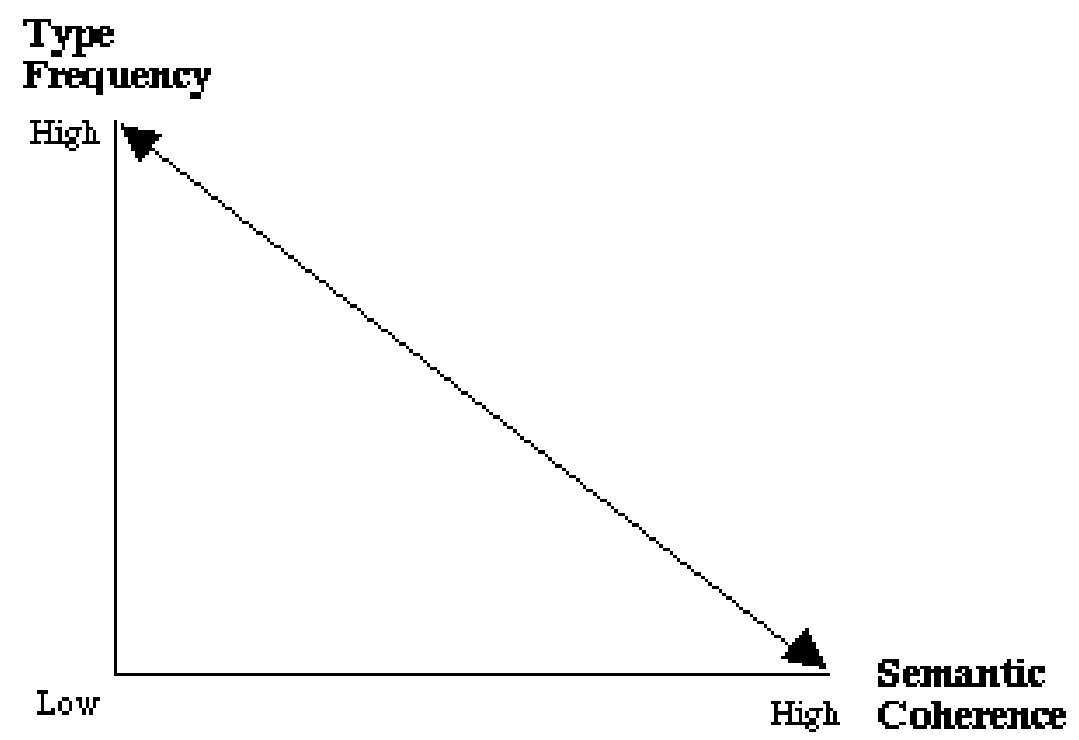

Figure 2. The inverse correlation between type frequency and semantic coherence

As high type frequency constructions (top of figure) are also semantically open and non-restricted (left of figure), they are expected to attract new verbs entering the language, resulting in high type frequency constructions increasing in frequency. Low type frequency constructions (bottom of figure) are usually more restricted semantically (right of figure) and are expected to gradually disappear unless they are high in token frequency, in which case they might be preserved as verb-specific lexically-filled constructions. If low type frequency constructions attract new verbs, this should be on the basis of high degree of similarity. High type frequency constructions can also attract verbs from low type frequency constructions, resulting in low type frequency constructions decreasing in frequency. Moreover, if two low type frequency constructions exchange verbs between themselves, it is expected that the construction lower in type frequency will lose verbs to the construction higher in type frequency.

On this approach, it is predicted that a rapid change in the vocabulary may speed up the development, precisely because the bulk of new verbs will be attracted by the high type frequency constructions, thereby lowering the type frequency of the low type frequency constructions, increasing the chances of them becoming extinct. It has been noted by various scholars that morphological case seems to have been lost at the same time as massive lexical borrowing is found, due to contact situations. This is discussed for Old English by Allen (1995), for Old Swedish by Wessén (1929, 1992), and for Scandinavian in general by Jahr (1995). Wessén argues that the case system was lost because the loan words could not easily adjust to the inflectional system. This has, however, been argued against by Norde (1994) who shows that the morphophonemic structure of the loan words cannot have constituted a problem for the noun inflection. It is nevertheless a fact that the breakdown of the case system in both English and Scandinavian coincides in time with massive lexical borrowings and that the correlation between loss of morphological case and the contact situation has thus so far not been appropriately included in the account of the development of case 
in Germanic. On the present account, it is expected that massive lexical borrowings will favor high type frequency constructions and disfavor the ones low in type frequency, and as will become evident below, this is borne out in Germanic. Therefore, the correlation between language contact and loss of morphological case is not an anomaly anymore but is satisfactorily accounted for on the present approach.

To sum up, the predictions of a usage-based constructional account of the development of case and argument structure constructions are the following:

- High type frequency constructions will attract new verbs and verbs from low type frequency constructions

- In the course of time, low type frequency constructions will decrease in their proportional type frequency since they do not attract new verbs, precisely because of their low type frequency and their restricted semantics

- If a low type frequency construction attracts new items, it will be on the basis of high degree of similarity

- The construction lowest in type frequency will disappear first

- Rapid changes in the vocabulary will speed up the development

I will now consider the development of case in the Germanic languages in the light of the predictions of a usage-based constructional account. I begin with Swedish (7.1), then I examine the development in English (7.2), next German (7.3) and subsequently I discuss the changes in frequency from Old Norse-Icelandic to Modern Icelandic (7.4). Finally, I present a usage-based constructional approach to the emergence of the 'blended' construction in Germanic (7.5).

\subsection{Swedish}

In the Mainland Scandinavian languages the argument structure constructions have merged and the case morphology disappeared. The genitive subject construction, for instance, is not documented in Old Swedish at all. This is also the construction lowest in type frequency in Modern Icelandic (cf. its marginal status in Table 3 above, evident by the fact that it subsumes much fewer subconstructions than the other case constructions). According to Delsing (1991) the first construction to disappear in Swedish was the infrequent genitive object construction. This had already taken place before 1350. Next to disappear is the now lowest type frequency accusative subject construction. That happens before 1400 (Falk 1997: 14-15). Around 1450 all case endings have been lost, which entails that the case distinction between nominative and dative subjects is lost for nouns, and the case distinction between accusative and dative objects as well. At this point in time, then, Swedish only exhibits two case forms on pronouns, i.e. nominative and non-nominative (or oblique). The only case frames that are now left in Swedish are the nominative subject construction and the former dative, now oblique, subject construction, although this is only visible on pronouns. According to Falk (1997: 187-188) the number of different verbs occurring in the oblique subject construction is as low as 38 (compared to 700 dative subject predicates in Icelandic). These verbs have either become associated with the nominative subject construction or fallen into disuse during the 16th and the 17th centuries. The last verb class to become associated with the nominative subject construction is the class of ditransitive verbs occurring in the oblique passive construction (where the indirect object has been promoted to subject). That happens around 1800 . 
It is interesting to note, however, that despite the low type frequency of the oblique subject construction, there are still documented cases of it being mildly productive during medieval times. Falk (1997: 51) reports on such examples:

\author{
Än sidhan honom iäfwadhe tok han til at sionka (ca. 1420) \\ but since him.OBL doubted took he to sink \\ 'But since he doubted he started sinking'
}

ty oer thz sa som mik toenker

(ca. 1500)

therefore is that such as me.OBL thinks

'That is why it is as I think'

The verbs iäfwa 'doubt' and toenka 'think' are conventionally associated with the nominative subject construction in Old Swedish. That these verbs occur in the oblique subject construction is presumably due to their lexical meaning, and the fact that their semantics is compatible with the semantics of the oblique subject construction.

To sum up, Swedish and Mainland Scandinavian in general have dealt with synonymous argument structure constructions by merging them, with a subsequent loss of the morphological case system. Moreover, according to the predictions of a usage-based construction grammar, the constructions lowest in type frequency should be the ones in most danger of disappearing. This prediction is borne out in Swedish, in that the most infrequent constructions disappeared first and the least infrequent constructions disappeared last.

\title{
7.2 English
}

According to Allen (1995: 211-220) the first case construction to disappear in English was the genitive object construction. That happened in two stages: first the genitive of the impersonal Acc-Gen and Dat-Gen disappeared, then the genitive of the Nom-Gen construction. This is identical to the development in Icelandic (see 7.4 below) where the Dat-Gen construction has already disappeared while the Nom-Gen has decreased in frequency from Old to Modern Icelandic. Allen (1995: 218-219) makes a point of the fact that genitive objects disappear in two stages, which on her generative approach is interpreted as if there is a structural difference between these two types of genitive objects. On the present approach, however, it is predicted that Acc-Gen and Dat-Gen disappear before Nom-Gen because of the differences in type frequency found between these constructions in Germanic. This prediction is also borne out.

Second, the distinction between accusative and dative case is completely lost in the end of the 13th century for nouns. It is, however, maintained for pronouns. Third, the oblique passive construction of ditransitives becomes infrequent in the late 14th century. Finally, the active oblique subject construction (as opposed to passives of ditransitives) remains in use until the 14th century, starts declining in the 15th century and is completely lost in the 16th century.

The productivity of the oblique subject construction has been amply documented in Middle English (see Seefranz-Montag 1983, Allen 1995), in that the construction attracts both borrowed and already existing verbs. Allen (1995: 250) reports on a modal verb occurring in the oblique subject construction instead of the conventionalized nominative subject construction: 
Wherefore us oghte ... have pacience.

Middle English

why us.OBL should ... have patience

'Why we should have patience.'

The internal order of distinctions being lost is the same in English as in Swedish, which is consistent with an overall assumption that the type frequency of the different verb classes may have been relatively similar in the different Germanic languages, with some minor deviations to be expected. ${ }^{3}$

Table 4. Case constructions in Modern English and Mainland Scandinavian

\begin{tabular}{ll}
\hline Nom \\
\hline Nom \\
Nom-Acc \\
Nom-PP \\
Nom-S \\
\hline
\end{tabular}

Compared to the case constructions in earlier Germanic (Table 3 above), the situation in both Swedish and English, after the loss of the morphological case, can be summarized as in Table 4, which shows that only the nominative subject construction, i.e. the construction highest in type frequency in Germanic, still exists. All the low type frequency constructions have disappeared from the two languages.

\subsection{German}

German differs from Swedish and English in that it has maintained its morphological case, exactly like Icelandic and Faroese, although it has clearly developed in the direction that the constructions lowest in type frequency have disappeared from the language, and the remaining low type frequency constructions have become even lower in type frequency in German.

The Nom-Acc, Nom-Dat and Nom-Gen constructions still exist in Modern German, but the Nom-Dat construction is only instantiated by approximately 100 verbs, while the corresponding figure for Modern Icelandic is 750 verbs (Maling

\footnotetext{
${ }^{3}$ There is one difference between the development of case in Swedish and English, namely the internal order of the loss of the oblique subject construction as opposed to the oblique passive construction of ditransitives. In Swedish the loss of the oblique subject construction precedes the loss of the oblique passive construction while the order is reversed in English (this reverse order of events has also been reported by Knudsen 1956: 36-41 for Danish). On a usage-based account this is expected to be a manifestation of differences in type frequency and semantic coherence between oblique subject predicates and ditransitives in the two languages, in that the oblique passive construction had higher type frequency than the oblique subject construction in Swedish as opposed to English, and vice versa. This might be because the vocabulary may not have been renewed at the same rate in the two languages. Obviously, extensive borrowing will increase the type frequency of the most productive construction, and hence reduce the type frequency of other less productive constructions. Another explanation for differences in type frequency of constructions in different languages is that verbs may be borrowed or coined in a particular language for one semantic field at a higher rate than for another semantic field, which in turn may result in differences in type frequency between constructions. However, as neither Falk (1997) nor Allen (1995) gives any numbers for the ditransitives they investigate, the matter cannot be determined here and now (although Falk explicitly states that she bases her analysis of the perseverance of the ditransitive construction on the fact that it is high in type frequency).
} 
2002: 31). ${ }^{4}$ The Nom-Gen construction is instantiated by ca. five predicates in Modern High German language use.

According to Seefranz-Montag (1983: 171-189) the genitive object of the AccGen and Dat-Gen constructions, as well as the genitive subject of genitive subject predicates, merged with nom/acc forms in the 13th century. Furthermore, most of the verbs occurring in the accusative and dative subject constructions have either fallen into disuse in German or been attracted by the nominative subject construction. However, during the Middle High German period there was a considerable variation between the different constructions, in that impersonal verbs could readily occur in the accusative, dative and the nominative subject construction. The dative subject construction attracted many verbs from the accusative subject construction, and the accusative subject construction has, likewise, attracted (somewhat fewer) verbs from the dative subject construction (1983: 162-163). That verbs were so easily exchanged between the accusative and dative subject constructions is a consequence of the fact that these constructions were very similar in meaning. Finally, German has maintained the dative passive construction. This is parallel to the Swedish situation in that the oblique subject construction disappears before the oblique passive construction of ditransitives.

Compared to the case constructions in earlier Germanic (Table 3 above), the remaining case constructions in Modern High German are the following:

Table 5. Case constructions in Modern High German

\begin{tabular}{lll}
\hline Nom & Acc & Dat \\
\hline Nom & Acc & Dat \\
Nom-Acc & Acc-Nom & Dat-Nom \\
Nom-Dat & Acc-PP & Dat-PP \\
$\dagger$ Nom-Gen & Acc-S & Dat-S \\
Nom-PP & & \\
Nom-S & & \\
\hline
\end{tabular}

The situation in Modern High German is such that the accusative/dative subject construction has more or less fallen into disuse, except with some Dat-Nom predicates, a few Acc-Nom predicates, and intransitive adjectival predicates of the type mir ist kalt (me is cold). Thus, most subjects in German are in the nominative case, most objects are in the accusative case, indirect objects are in the dative case and nominal attributes are in the genitive case. Hence, all the high type frequency case constructions have been maintained in Modern High German, at the expense of the low type frequency constructions which have either disappeared or are only instantiated by a few predicates in the modern language.

\subsection{Icelandic}

The construction lowest in type frequency in Old Norse-Icelandic is presumably the Dat-Gen construction, as it was instantiated by only two verbs, batna 'get better' and létta 'abate (of illness)'. This construction is also the only case construction that has

\footnotetext{
${ }^{4}$ Maling counts 140 dative object predicates. However, around 40 of these are Dat-Nom predicates where the dative has traditionally been regarded as an object (for arguments against an object analysis of the dative in Dat-Nom constructions in Germanic, cf. Barðdal and Eythórsson 2003b, Eythórsson and Barðdal 2005, Barðdal 2006b, Barðdal and Eythórsson 2006). I exclude these 40 from the present number of dative object predicates as I am first and foremost counting Nom-Dat predicates here and not Dat-Nom predicates.
} 
disappeared. Not surprisingly, batna and létta were subsumed by the more common Dat-Nom construction which was much higher in type frequency (a count of alternating Dat-Nom predicates in Modern Icelandic reveals 111 predicates, cf. Barðdal 2001b). This is a natural development as the two case constructions are similar in both form and meaning. That is, both constructions are two-place constructions with a dative subject, and all the predicates shared by them are experience-based. Therefore, the Dat-Gen construction can be regarded as a proper subconstruction of the more general dative subject construction:

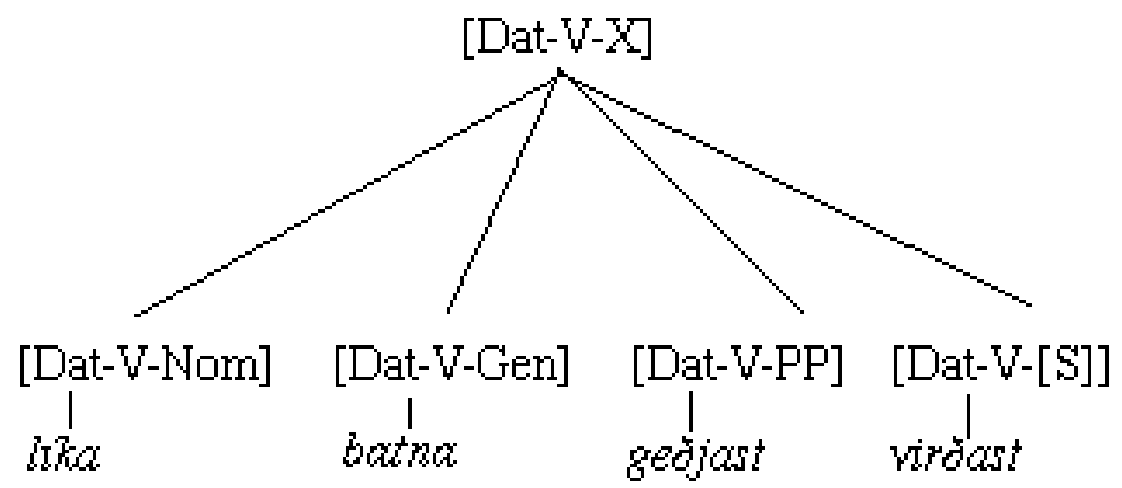

Figure 3. The Dative subject construction and its subconstructions

Examples of the verb-specific constructions in Figure 3 are given in (25) below:

(29)a. Mér likar pessi vinna rosalega vel ... me.DAT likes this work.NOM exceedingly well 'I really like this job ...' (torleifur.blogspot.com/2005_08_01_torleifur_archive.html)'

b. Pormóði batnaði pá skjótt augnaverkjarins og ... Thormod.DAT got-better then swiftly eye-pain-the.GEN 'Thormod then swiftly recovered from the eye pain ...'

c. Mér geðjaðist að hugmyndinni um hugleiðslu. (Fóstbræðra saga 1987: 802) me.DAT liked at idea-the of meditation 'I liked the idea of meditating.'

(www.al-anon.is/hlekkurinn.asp?Frettir_ID=9501)

d. Mér virðist sem að foestir peirra hafi tíma til að hlusta ... me.DAT seems as if fewest them have time for to listen 'It seems to me that the fewest of them have time to listen ...'

(www.doktor.is/grein/efni/grein.asp?id_grein=3366\&flokkur=16)

In contemporary Icelandic the Dat-Gen construction does not exist; Therefore a figure like Figure 3 for Modern Icelandic would not contain the Dat-Gen construction. Both batna and létta are now Dat-Nom predicates. It is also a fact that verbs which occur in one of the subconstructions in Figure 3 readily occur in some of the other. The verb lika 'like' is one example; It can occur in all three subconstructions of the dative subject construction:

(30)a. Mér likar pessi vinna rosalega vel ... Dat-Nom me.DAT likes this work.NOM exceedingly well 'I really like this job ...' 


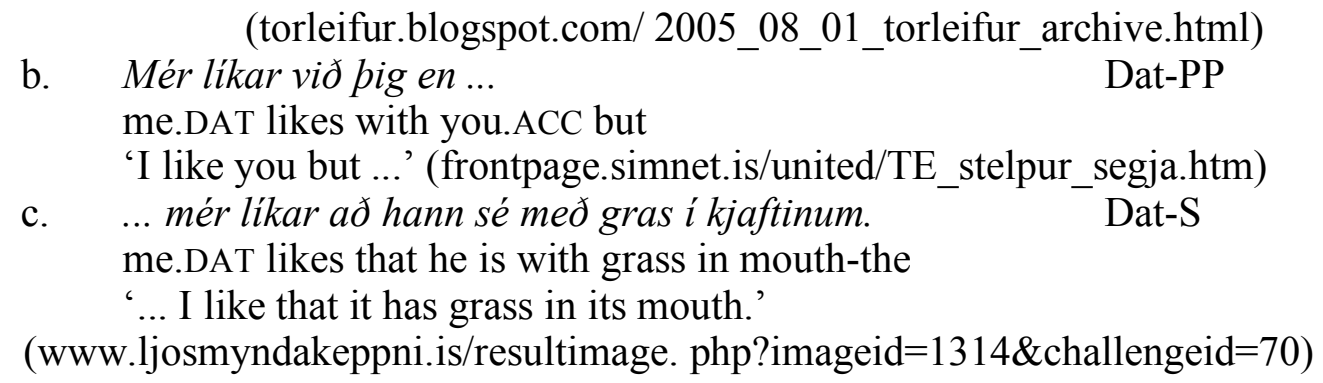

This analysis, based on the higher type frequency of the Dat-Nom construction as opposed to the Dat-Gen construction, and their similarity in form and meaning, makes the prediction that an alleged lexical genitive object will change into an alleged structural nominative object in the history of Icelandic, a change which is unexpected on the lexical-to-structural-case account, as on that account one would expect the object to change into accusative and not nominative (see section 6 above). Since the Dat-Nom construction is higher in type frequency than the Dat-Gen construction (at least 111 predicates vs. two), it attracts verbs from the Dat-Gen construction, gradually causing it to fall into disuse. The change from genitive objects to nominative objects is thus not an anomaly on the current approach. The same factors are responsible for the change from genitive objects to accusative objects with verbs like purfa 'need' in (15) above. As mentioned in section 6, purfa was originally a Nom-Gen verb, but the Nom-Gen construction was and is a low type frequency construction. The Nom-Acc, in contrast, is the highest in type frequency of all transitive constructions in Icelandic. Because of that, it attracts verbs from the NomGen construction.

Another change in case marking in Icelandic, subject to considerable attention in the literature, is dative substitution, a change which entails that verbs conventionally occurring in the accusative subject construction have started occurring more and more in the dative subject construction. This was shown in (12) above, repeated here for convenience:

$$
\begin{aligned}
& \text { Mig langar }>\text { Mér langar } \\
& \text { me.ACC longs }>\text { me.DAT longs }
\end{aligned}
$$

This change has also been documented in the history of German (see section 7.3 above). In Icelandic it started in the late 19th century (Halldórsson 1982), and it is expected on a usage-based constructional approach, as the accusative subject construction is much lower in type frequency than the dative subject construction (see Table 6 below), and the two constructions (partly) share the same semantics. It is also expected that accusative experience-based predicates be attracted by the dative subject construction and not the nominative subject construction, as the dative subject construction is much more restricted in its semantics, and semantically much closer to the accusative subject construction than the nominative subject construction which is a semantically open construction, instantiated by verbs from all semantic fields.

Let us now compare frequency figures for subjects and objects in Old NorseIcelandic and Modern Icelandic texts (see section 3 above for information about the corpus). Table 6 gives the number of subjects in different case form in both language 
stages. ${ }^{5}$ The table shows first and foremost that the type frequency of nominative subjects has gone up on a per/word basis of ca. 9\%. It also shows that the type frequency of dative subjects has gone down from 72 to 48 types in the text corpus, a reduction of approximately $8 \%$. Accusative and genitive subjects, however, have remained stable in type frequency between the two periods of Icelandic. A closer look at the accusative and genitive subject constructions reveals that some of the predicates instantiating them in Old Norse-Icelandic have fallen into disuse and some are shared across the two language stages (see Appendix B in Barðdal 2001a). This last fact suggests that the two construction have been maintained in Icelandic, because the few lexical items instantiating them have not fallen into disuse. However, it is possible that the accusative and genitive subject constructions have gone down in type frequency, although the present text corpus is not large enough to capture this.

Table 6. Subject frequency in Old Norse-Icelandic and Modern Icelandic

\begin{tabular}{lrrrr}
\hline & \multicolumn{2}{c}{ Old Norse-Icelandic } & \multicolumn{2}{c}{ Modern Icelandic } \\
\hline & $\mathrm{N}$ & $\mathrm{f}$ & $\mathrm{N}$ & $\mathrm{f}$ \\
\hline Nom & 299 & $76.3 \%$ & 406 & $85.3 \%$ \\
Acc & 14 & $3.5 \%$ & 15 & $3.1 \%$ \\
Dat & 72 & $18.4 \%$ & 48 & $10.1 \%$ \\
Gen & 7 & $1.8 \%$ & 7 & $1.5 \%$ \\
\hline & 392 & $100 \%$ & 476 & $100 \%$ \\
\hline
\end{tabular}

Consider now Table 7 on object frequency which illustrates that the Nom-Acc construction is proportionally higher in type frequency in the Modern Icelandic texts than in the Old Norse-Icelandic texts. The difference is around 6\%, i.e. from 52.1 to $58.4 \%$. It is interesting in this context that the dative object construction has not only remained stable from Old Norse-Icelandic to Modern Icelandic but also that there has been a slight increase in the type frequency of Nom-Dat predicates too, namely of ca. $3 \%$. This may suggest that the minimum type frequency needed for a category to be stable is around $30 \%$ of the types, although more research is needed to establish that beyond doubt. The increase in the type frequency of Nom-Acc and Nom-Dat has happened at the cost of verbs selecting for nominative and genitive objects, since their type frequency is drastically reduced.

Table 7. Object frequency in Old Norse-Icelandic and Modern Icelandic

\begin{tabular}{lrrrrll}
\hline & Old Norse-Icelandic & \multicolumn{3}{c}{ Modern Icelandic } & \\
\hline & $\mathrm{N}$ & $\mathrm{f}$ & $\mathrm{N}$ & $\mathrm{f}$ & \\
\hline Dat-Nom & 33 & $10.0 \%$ & 11 & $2.7 \%$ & \\
Nom-Acc & 173 & $52.1 \%$ & 237 & $58.4 \%$ & $? ?$ \\
Nom-Dat & 105 & $31.6 \%$ & 141 & $34.7 \%$ & $? ?$ \\
Nom-Gen & 21 & $6.3 \%$ & 17 & $4.2 \%$ & $? ?$ \\
\hline & 332 & $100 \%$ & 406 & $100 \%$ & \\
\hline
\end{tabular}

These tables show that the constructions highest in type frequency have increased their type frequency, i.e. the nominative subject, accusative object and dative object constructions, and the ones lowest in type frequency have gone down in frequency, i.e. the dative subject and the genitive object constructions. Two constructions are at

\footnotetext{
${ }^{5}$ For ease of counting, Table 6 only specifies nominative subject case for two-place predicates, i.e. Nom-Acc, Nom-Dat and Nom-Gen, leaving out intransitive verbs with nominative subjects.
} 
the same size, accusative and genitive subject constructions, although they may also have gone down in type frequency, not detectable here because of the smallness of the corpora. Table 8, thus, presents the case constructions in Modern Icelandic.

Table 8. Case constructions in Icelandic

\begin{tabular}{lccc}
\hline Nom & Acc & Dat & Gen \\
\hline Nom & Acc & Dat & Gen \\
Nom-Acc & tAcc-Nom & Dat-Nom & tGen-Nom \\
Nom-Dat & Acc-Acc & tDat-Gen & Gen-PP \\
Nom-Gen & tAcc-Gen & Dat-PP & Gen-S \\
Nom-PP & Acc-PP & Dat-S & \\
Nom-S & Acc-S & & \\
\hline
\end{tabular}

As evident from Table 8, there are four case constructions, marked with $\mathbf{t}$, which have either disappeared in Icelandic or gone drastically down in type frequency (the relevant predicates have either fallen into disuse or been attracted by other case constructions higher in type frequency). The Acc-Nom, Acc-Gen and Gen-Nom are only instantiated by one to four predicates each (cf. Barðdal 2008: Ch. 3). These are also the case constructions which were lowest in type frequency in Old NorseIcelandic. Hence, of the four languages discussed here, Icelandic has changed the least from Proto-Germanic and maintained most of the case constructions common to the Germanic language area.

Icelandic also differs from the three other Germanic languages discussed above in that a large degree of the vocabulary has been maintained from Old Norse-Icelandic to Modern Icelandic (cf. Kvaran 1996, Rögnvaldsson 1997). A comparison of the predicates occurring in the present corpus with a list of the 100 most frequent predicates in Modern Icelandic (Pind 1991) reveals that of the 91 most frequently occurring transitive predicates in Modern Icelandic language use, 83 predicates occur in the Modern Icelandic texts and 82 in the Old Norse-Icelandic texts. This suggests more than a $90 \%$ overlap in the verbal vocabulary between the two language stages. This is furthermore in accordance with my hypothesis that there is a correlation between the rate of the vocabulary replacement and the development of case in Germanic, shown in Table 9.

Table 9. The correlation between language contact and loss of case

$\begin{array}{ll}\text { Vocabulary Replacement: } & \text { English }<\text { Swedish }<\text { German }<\text { Icelandic } \\ \text { Development of Case: } & \text { English }<\text { Swedish }<\text { German }<\text { Icelandic }\end{array}$

This correlation is predicted on a usage-based constructional approach, which takes type frequency as its point of departure. That is, English leads the development with the most extensive borrowings of all the languages considered here, beginning in the 11 th century. Swedish has also been involved in much language contact, with massive Low German influence beginning in the late 13th century. German has not had the extensive replacement of the vocabulary found in both English and Swedish, but it has nevertheless been more influenced than Icelandic, which is the least influenced language of the four. Obviously, the faster the vocabulary is renewed, the sooner the high type frequency constructions will increase in type frequency, and the sooner the low-frequency constructions will decrease in their type frequency, as the renewal of the vocabulary favors the construction highest in type frequency and disfavors the 
ones lower in type frequency. Therefore, on a usage-based constructional approach it is predicted that the language that has been subject to most foreign influence will lead the development, and that the least influenced language will lag behind. That prediction is borne out for Germanic, as English leads the development and Icelandic lags behind.

In sum, the predictions of a usage-based constructional approach to changes in case are borne out for Icelandic, as the high type frequency constructions have gained in type frequency while the low type frequency constructions have lost in type frequency. Changes in case marking of individual verbs or verb classes, like the change from genitive objects to either nominative objects or accusative objects, and the change from accusative subjects to dative subjects, are motivated by both the type frequency of the relevant constructions and the similarities in form and meaning between them. The breakdown of the case and argument structure constructions has gone furthest in English, then Swedish, then German, and shortest in Icelandic. The development correlates with language contact, as rapid changes in the vocabulary will speed up the process. Indeed, the breakdown of the case system in the individual Germanic languages correlates, not only with the density of the contact, but also with the time span of the breakdown and the loss of the particular case constructions.

\subsection{The 'Blended' Construction}

In the process of the breakdown of the case system, many Germanic languages have developed the so-called 'blended' construction, where the nominative object of the former Dat-Nom construction, realized as Obl-Nom at this point in the development, turns up in the accusative, and is hence realized as Obl-Obl. Examples (18-20) above from Middle English, Old Swedish and Modern Faroese illustrate this (repeated here for convenience):

for pi ðat him areowe ow

Middle English

for that that him.OBL pity you.OBL

'so that he would pity you' (Allen 1995: 238)

Honom thykte sik wara jenom lystelikom stadh

Old Swedish he.OBL thought himself.OBL be in a pleasing place

'He felt as if he was in a pleasant place.' (Falk 1997: 77)

\section{Mcer dámar vael hasa bókina.}

Modern Faroese

I.DAT like well this book.ACC

'I like this book.' (Barnes 1986: 33)

Allen reports that traditionally this blend has been regarded as an accident in the prevalent language material. She argues, however, and quite convincingly so in my opinion, that the blend deserves a better explanation than that. Given that the blend seems to arise independently in the Germanic languages, it certainly does not seem like an accident, but requires a systematic explanation. Allen herself argues that the blend emerges when her postulated case-marking hierarchy disappears. However, she also argues that the case-marking hierarchy disappeared on the basis of the existence of the blend, thus her account is not independently motivated. Falk (1997: 77-78), however, argues that the blend is a consequence of a change from lexical case to structural case on objects. 
The problem with both these analyses is that they do not address the question of why only the object should become 'structurally' case marked and not the subject. In other words, why should oblique subjects retain their non-canonical case marking longer than nominative objects in a system which is otherwise in the process of falling apart? That is, since the case of the subject and the object does not change at the same time, why does not a Nom-Nom construction emerge instead of an Obl-Obl? This is a legitimate question as it is not a priori given that the object must change its case form first and the subject later. It is equally plausible and equally logical that the subject changes its case form before the object, but that does not happen in Middle English, Old Swedish and Modern Faroese. On the usage-based constructional account laid out here, it is predicted that subjects will become nominative and objects accusative because of the high type frequency of nominative subjects and accusative objects, and that the case form higher in type frequency will resist the change longer because it is more entrenched in the system. As I have already outlined for Icelandic above, the nominative object is most prevalent in the Dat-Nom constructions whereas dative subjects can select for different types of complements. The dative subject construction comprises around 700 predicates (see the discussion around Table 3 above) while the Dat-Nom subconstruction comprises only 111 predicates in Modern Icelandic (Barðdal 2001b: 54-55). Hence, the dative subject construction is much higher in type frequency than the nominative object construction and is thereby predicted to maintain its case form longer. That prediction is borne out for the 'blended' construction in the history of the Germanic languages, which in turn sustains the validity of the usage-based constructional model.

\section{Summary}

In this article I have given an overview of five existing hypotheses on the development of the morphological case system in Germanic. First, I have examined the claim that loss of case is due to phonological erosion of unstressed syllables, which turns out to be problematic since the erosion does not target verbal inflection to the same degree as nominal inflection, for instance in Swedish. Assuming a development from synthetic to analytic is also problematic for Germanic, as there are restrictions found on the Ditransitive in Icelandic, a case language, which are not found in English, a non-case language. A development from synthetic to analytic also predicts that the ditransitive construction should not be productive in Germanic, nor the dative object construction in Icelandic. Neither of these predictions is borne out. I have also discussed hypotheses that assume that the loss of morphological case in Scandinavian/Germanic is due to the word order becoming more rigid and hence taking over the function of signaling grammatical relations. However, I have found that the predictions of this hypothesis are not borne out either, since Icelandic and Dutch do not conform to the predicted pattern. I have, then, investigated whether the loss of morphological case may be due to the emergence of the definite article in Scandinavian and have found that both Icelandic and Faroese constitute counterexamples to such a claim. All these approaches, however, are based on specific domains of grammar, i.e. cross-linguistic patterning or co-occurrence of certain typological features. In contrast, the approach that loss of case is due to lexical case being replaced with structural case is a specific theory-internal explanation which is not borne out either for Icelandic, as there are documented changes in case assignment of verbs in both directions, i.e. lexical case seems to replace structural case and structural case seems to replace lexical case in the history of Icelandic. 
Instead, I have outlined a usage-based constructional approach to the loss of morphological case that is in accordance with all the relevant data. I have presented an analysis of the development in four Germanic languages: Icelandic, Swedish, English and German. The analysis is based on the idea that the original case constructions were either synonymous or very similar in meaning, and that logically there are two ways for languages to eliminate this synonymy: either (i) by high frequency constructions attracting verbs conventionally occurring in the less frequent constructions, thereby causing less frequent constructions to fall into disuse, or (ii) by merging synonymous argument structure constructions, with a subsequent loss of morphological case. English, Dutch and Mainland Scandinavian have taken the latter alternative, while Icelandic, Faroese and German have gone the former way. Also, German has developed much farther in this direction than Icelandic.

There is, moreover, a clear correlation between the rate of the vocabulary renewal and the development of case, which is predicted on a usage-based constructional approach relying on the type frequency of the constructions in question. English leads the development with the most extensive borrowings of all the languages being considered here, beginning in the 11th century. Swedish has also been involved in much language contact, with massive Low German influence beginning in the late 13th century. German has not had the extensive replacement of the vocabulary found in both English and Swedish, but it has nevertheless been more influenced than Icelandic, which is the least influenced language of the four. Obviously, the faster the vocabulary is renewed, the sooner the high type frequency constructions increase in type frequency, and the sooner the low-frequency constructions decrease in their type frequency. Thus, on a usage-based constructional approach it is predicted that the language which has been subject to most foreign influence will lead the development, and the language that has been least influenced will lag behind. That prediction is borne out for Germanic.

Finally, I have discussed the emergence of the 'blended' construction in the history of the Germanic languages, a construction which is formally a mixture of the Dat-Nom and Nom-Acc constructions. Hitherto, the explanations offered in the literature for the blend have either assumed that it is an accident in the prevalent language material, or that it demonstrates that 'lexical' case is being replaced by 'structural' case. These analyses, however, have not offered any systematic explanation as to why the case of the object should be replaced first instead of the subject case. I have proposed a usage-based constructional analysis which predicts that the more entrenched argument, i.e. the one highest in type frequency, will resist the change longer. This prediction is borne out for the blend in the history of Germanic, thus sustaining the validity of a usage-based construction grammar.

\section{References}

Allen, Cynthia L. 1995. Case marking and reanalysis: Grammatical relations from Old to Early Modern English. Oxford: Oxford University Press.

Andrews, Avery D. 1976. The VP complement analysis in Modern Icelandic. Proceedings of the North East Linguistic Society 6: 1-21.

Anward, Jan and John Swedenmark. 1997. ¡Kasus nej, bestämdhet ja! Om Möjliga modeller av nominalböjningens utveckling i svenskan [iCase no, definiteness yes! On possible models on the development of the noun declension in Swedish]. P. Åström (ed.), 21-34. Stockholm: Institutionen för nordiska språk [MINS 44]. 
Askedal, Jan Ola. 2001. "Oblique subjects," structural and lexical case marking: Some thoughts on case assignment in North Germanic and German. Grammatical Relations and Change, J. T. Faarlund (ed.), 67-97. Amsterdam: John Benjamins.

Barðdal, Jóhanna. 1993. Accusative and dative case of objects of some transitive verbs in Icelandic and the semantic distinction between them. Flyktförsök: Kalasbok till Christer Platzack på femtioårsdagen 18 november 1993, från doktorander och dylika, 1-13. Lund.

Barðdal, Jóhanna. 1999. Case and argument structure of some loan verbs in 15th century Icelandic. Alla tiders språk: En Vänskrift till Gertrud Pettersson november 1999. I. Haskå and C. Sandqvist (eds.), 9-23. Lund: Institutionen för nordiska språk [Lundastudier i Nordisk språkvetenskap A 55].

Barðdal, Jóhanna. 2001a. Case in Icelandic - A synchronic, diachronic and comparative approach [Doctoral Dissertation]. Lund: Dept. of Scandinavian Languages [Lundastudier i Nordisk Språkvetenskap A57].

Barðdal, Jóhanna. 2001b. The perplexity of Dat-Nom verbs in Icelandic. Nordic Journal of Linguistics 24: 47-70.

Barðdal, Jóhanna. 2003. Case and argument structure of novel verbs of communication in Icelandic. Grammar in focus: Festschrift for Christer Platzack 18 November 2003, Vol. II, L.-O. Delsing, C. Falk, G. Josefsson and H. Á. Sigurðsson (eds.), 25-35. Lund: Department of Scandinavian Languages.

Barðdal, Jóhanna. 2006a. Predicting the productivity of argument structure constructions. To appear in Berkeley Linguistic Society 32.

Barðdal, Jóhanna. 2006b. Construction-specific properties of syntactic subjects in Icelandic and German. Cognitive Linguistics 17(1): 39-106.

Barðdal, Jóhanna. 2007. The lexical and semantic range of the ditransitive construction in the history of (North) Germanic. Functions of Language 14(1): 930 .

Barðdal, Jóhanna. 2008. Productivity: Evidence from case and argument structure in Icelandic. Amsterdam: John Benjamins.

Barðdal, Jóhanna and Thórhallur Eythórsson. 2003a. The change that never happened: The story of oblique subjects. Journal of Linguistics 39(3): 439-472.

Barðdal, Jóhanna and Thórhallur Eythórsson. 2003b. Icelandic vs. German: Oblique subjects, agreement and expletives. Chicago Linguistic Society 39(1): 755-773.

Barðdal, Jóhanna and Thórhallur Eythórsson. 2006. Control infinitives and case in Germanic: 'Performance error' or marginally acceptable constructions. Case, Valency and Transitivity, L. Kulikov, A. Malchukov and P. de Swart (eds.), 147177. Amsterdam: John Benjamins.

Barlow, Michael and Suzanne Kemmer (eds.). 2000. Usage-Based Models. Houston: Athelstan.

Barnes, Michael P. 1986. Subject, nominative and oblique case in Faroese. Scripta Islandica 37: 13-46.

Blake, Barry. 2001. Case. Cambridge: Cambridge University Press.

Boas, Hans. 2003. A constructional approach to resultatives. Stanford: CSLI Publications

Bybee, Joan. 1995. Regular morphology and the lexicon. Language and Cognitive Processes 10(5): 425-455.

Croft, William. 2003. Lexical rules vs. constructions: A false dichotomy. Motivation in language: Studies in honour of Günter Radden. H. Cuyckens, Th. Berg, R. Dirven, and K1.-U. Panther (eds.), 49-68. Amsterdam: John Benjamins. 
Croft, William. 2001. Radical construction grammar: Syntactic theory in typological perspective. Oxford: Oxford University Press.

Croft, William and D. Alan Cruse. 2004. Cognitive linguistics. Cambridge: Cambridge University Press.

Delsing, Lars-Olof. 1991. Om genitivens utveckling i fornsvenskan [On the development of the genitive in Old Swedish]. Studier $i$ svensk språkhistoria 2, S.-G. Malmgren and B. Ralph (eds.), 12-30. Göteborg: Acta Universitatis Gothoburgensis.

Eyrbyggja saga. 1987. Íslendinga sögur og paettir I. B. Halldórsson, J. Torfason, S. Tómasson and Ö. Thorsson (eds.), 537-624. Reykjavík: Svart á hvítu.

Eythórsson, Thórhallur. 2000. Dative vs. nominative: Changes in quirky subjects in Icelandic. Leeds Working Papers in Linguistics 8: 27-44.

Eythórsson, Thórhallur. 2002. Changes in subject case marking in Icelandic. Syntactic effects of morphological change. D. Lightfoot (ed.), 196-212. Oxford: Oxford University Press.

Eythórsson, Thórhallur and Jóhanna Barðdal. 2005. Oblique subjects: A common Germanic inheritance. Language 81(4): 824-881.

Faarlund, Jan Terje. 2001 The Notion of oblique subject and its status in the history of Icelandic. Grammatical Relations and Change. J. T. Faarlund (ed.), 99-135. Amsterdam: John Benjamins.

Falk, Cecilia. 1997. Fornsvenska upplevarverb [Experiencer verbs in Old Swedish]. Lund: Lund University Press.

Falk, Hjalmar and Alf Torp. 1900. Dansk-norskens syntax $i$ historisk fremstilling [The syntax of Danish-Norwegian from a diachronic perspective]. Kristiania: Aschehoug.

Fóstbræðra saga. 1987. Íslendinga sögur og paettir II. B. Halldórsson, J. Torfason, S. Tómasson and Ö. Thorsson (eds.), 775-851. Reykjavík: Svart á hvítu.

Fried, Mirjam. 2005. A frame-based approach to case alternations: The swarm-class verbs in Czech. Cognitive Linguistics 16(3): 475-512.

Goldberg, Adele E. 1995. Constructions: A construction grammar approach to argument structure. Chicago: University of Chicago Press.

Goldberg, Adele E. 2005. Constructions at Work: The Nature of Generalization in Language. Oxford: Oxford University Press.

Gísla saga Súrssonar. 1987. Íslendinga sögur og paettir II. B. Halldórsson, J. Torfason, S. Tómasson and Ö. Thorsson (eds.), 852-898. Reykjavík: Svart á hvítu.

Halldórsson, Halldór. 1982. Um méranir: Drög að samtímalegri og sögulegri athugun [About dativizings: Preliminaries of a synchronic and diachronic investigation]. Íslenskt mál og almenn málfrceði 4: 159-189.

Holmberg, Anders. 1994. Morphological parameters in syntax: The case of Faroese. Report 35: 21-62. Umeå: Institutionen för lingvistik, Umeå Universitet.

Hænsna-Póris saga. 1987. Íslendinga sögur og peettir II. B. Halldórsson, J. Torfason, S. Tómasson and Ö. Thorsson (eds.), 1417-1436. Reykjavík: Svart á hvítu.

Ívens saga. 1979. F. W. Blaisdell (ed.). Kaupmannahöfn: C.A. Reitzels forlag [Editiones Arnamagnæanæ Series B, vol. 18].

Jahr, Ernst Håkon. 1995. Nedertysk og nordisk: språksamfunn og språkkontakt i Hansa-tida [Middle low German and Scandinavian: Language society and language contact during the Hansa period]. Nordisk og nedertysk: Språkkontakt og språkutvikling i seinmellomalderen. E. H. Jahr (ed.), 9-28. Oslo: Novus.

Jónsson, Jóhannes Gísli. 1996. Clausal architecture and case in Icelandic. Doctoral dissertation, University of Massachusetts Amherst. 
Jónsson, Jóhannes G. 2003. Not so quirky: On subject case in Icelandic. New perspectives on case and case theory. E. Brandner and H. Zinsmeister (eds.), 127164. Standford: CSLI Publications.

Jónsson, Jóhannes G. and Thórhallur Eythórsson. 2005. Variation in subject case marking in Insular Scandinavian. Nordic Journal of Linguistics 28(2): 223-245.

Kay, Paul and Charles Fillmore. 1999. Grammatical constructions and linguistic generalizations: The What's X Doing Y? construction. Language 75: 1-34.

Kemenade, Ans van. 1987. Syntactic case and morphological case in the history of English. Dordrecht: Foris.

Knudsen, Tryggve. 1956. Kasusloere I [Studies in case 1]. Oslo: Universitetsforlaget.

Kvaran, Guðrún. 1996. Pættir úr sögu orðaforðans [On the history of the Icelandic vocabulary]. Erindi um islenskt mál, 35-48. Reykjavík: Íslenska málfræðifélagið.

Lehmann, Christian. 1985. Latin case relations in typological perspective. Syntaxe et Latin. C. Touratier (ed.), 81-102. Aix-en-Provence: Université de Provence.

Lightfoot, David. 1999. The development of language: Acquisition, change, and evolution. Malden, MA: Blackwell.

Luraghi, Sylvia. 1987. Patterns of case syncretism in Indo-European languages. Papers from the VIIth International Conference on Historical Linguistics. A. G. Ramat, O. Carruba, and G. Bernini (eds.), 355-371. Amsterdam: John Benjamins.

Maling, Joan. 2002. Pað rignir págufalli á Íslandi [It is raining dative in Iceland]: Verbs with dative objects in Icelandic. Íslenskt mál og almenn málfraði 24: 31105 [Also published in a slightly different English version in Working Papers in Scandinavian Syntax 70: 1-60, 2002].

Michaelis, Laura A. and Josef Ruppenhofer. 2001. Beyond alternations: A constructional model of the German applicative pattern. Stanford: CSLI Publications.

Neeleman, Ad and Fred Weerman. 1999. Flexible syntax: A theory of case and arguments. Dordrecht: Kluwer.

Norde, Muriel. 1994. De lågtyska lånorden och kasussystemets förenkling i svenskan [Loan words from Middle Low German and the breakdown of the case system in Swedish]. Dialektkontakt, språkkontakt och språkförändring $i$ Norden. U.-B. Kotsinas and J. Helgander (eds.), 98-106. Stockholm: Institutionen för nordiska språk [MINS 40].

Óttars páttur svarta (eftir Bergsbók). 1987. Íslendinga sögur og pcettir III. B. Halldórsson, J. Torfason, S. Tómasson and Ö. Thorsson (eds.), 2205-2206. Reykjavík: Svart á hvítu.

Physiologus. 1991. Heimskringla III. B. S. Kristjánsdóttir, B. Halldórsson, J. Torfason and Ö. Thorsson (eds.), 43-55. Reykjavík: Mál og menning.

Pind, Jörgen (ed.). 1991. Íslensk orðtiððnibók [Icelandic word frequency book]. 1991. Reykjavík: Orðabók Háskólans,

Rögnvaldsson, Eiríkur. 1983. Págufallssýkin og fallakerfi í íslensku [Dative sickness and the case system in Icelandic]. Skíma 16:3-6.

Rögnvaldsson, Eiríkur. 1995. Old Icelandic: A non-configurational language. NOWELE 26: 3-29.

Rögnvaldsson, Eiríkur. 1997. Orðafar Íslendinga sagna [Wordings in the Icelandic Sagas]. Milli himins og jarðar. A. Agnarsdóttir, P. Pétursson and T. H. Tulinius, 271-286. Reykjavík: Háskólaútgáfan.

Sapir, Edward. 1921. Language. New York: Harcourt. 
Seefranz-Montag, Ariane v. 1983. Syntaktische Funktionen und Wortstellungsveränderung. Die Entwicklung 'subjektloser' Konstruktionen in einigen Sprachen. München: Wilhelm Fink Verlag [Studien zur Theoretischen Linguistik 3].

Sigurðsson, Halldór Ármann. 1989. Verbal syntax and case in Icelandic. Doctoral dissertation, Lund University.

Smith, Henry. 1994. 'Dative Sickness' in Germanic. Natural Language and Linguistic Theory 12: 675-736.

Svavarsdóttir, Ásta. 1982. "Págufallssýki" ["Dative Sickness"]. Íslenskt mál og almenn málfrceði 4: 19-62.

Svavarsdóttir, Ásta, Gísli Pálsson and Pórólfur Pórlindsson. 1984. Fall er fararheill: Um fallnotkun með ópersónulegum sögnum [Fall is a sign of luck: On case use with impersonal verbs]. Íslenskt mál og almenn málfrceði 6: 33-55.

Vennemann, Theo. 1974. Topics, subjects and word order: From SXV to SVX via TVX. Historical linguistics 1. J. M. Anderson and C. Jones (eds.), 339-376. Amsterdam: Elsevier.

Wessén, Elias. 1929. Om det tyska inflytandet på svenskt språk under medeltiden [On the German influence on the Swedish language during the Middle Ages]. Nordisk Tidsskrift 5: 265-280.

Wessén, Elias. 1992. Svensk språkhistoria 1 [Swedish language history 1]. Stockholm: Institutionen för nordiska språk [NNSS 4].

Wisser, F. Th. 1963. An historical syntax of the English language I: Syntactical units with one verb. Leiden: Brill.

Yip, Moira, Joan Maling and Ray Jackendoff. 1987. Case in tiers. Language 63: 217250.

Zaenen, Annie, Joan Maling and Höskuldur Thráinsson. 1985. Case and grammatical functions: The Icelandic passive. Natural Language and Linguistic Theory 3: 441483. 